\title{
The Effect of Theory of Planned Behavior-Based Education in Adopting the Urinary Tract Infection Prevention Behavior in Pregnant Women: A randomized Controlled Trial
}

\section{Sheida Moradpour}

Isfahan University of Medical Sciences

Hossein Shahnazi ( $\sim$ h_shahnazi@yahoo.com)

Isfahan University of Medical Sciences School of Public Health https://orcid.org/0000-0002-59013901

Akbar Hassanzadeh

Isfahan University of Medical Sciences

Research article

Keywords: Urinary Tract Infection, Theory of Planned Behavior (TPB), Pregnant women

Posted Date: August 13th, 2020

DOI: https://doi.org/10.21203/rs.3.rs-56841/v1

License: (a) (i) This work is licensed under a Creative Commons Attribution 4.0 International License.

Read Full License 


\section{Abstract}

\section{Background}

Urinary tract infection (UTI) is a common infection in women, and it is more likely to occur during pregnancy due to mechanical and hormonal changes in pregnant women. Urinary tract infections can cause many complications for both mother and fetus. Given the roles of health behavior in the prevention of urinary tract infections and the nature of the theory of planned behavior-based education in behavioral change, the present study aimed to determine the effect of the theory of planned behavior-based education in teaching the urinary tract infection prevention behavior in pregnant women.

Methods

The present study was a randomized controlled trial in which 100 pregnant women, who visited the comprehensive health service centers of Zarinshahr City, were randomly divided into two groups, intervention and control, containing 50 individuals. The data collection tools were a urine test and a questionnaire designed based on the theory of planned behavior. Five education sessions were held based on the constructs of the theory of planned behavior. We analyzed the effect of education review and data using independent t-tests, Mann-Whitney test, chi-square test, and repeated measures ANOVA (analysis of variance) one and three months after the educational intervention.

Results

After implementing the educational intervention, the mean scores of knowledge and constructs of the theory of planned behavior significantly increased in the intervention group over time $(P<0.001)$, while the difference was not significant in the control group over time. After the educational intervention, the incidence of urinary tract infections was $4.3 \%$ in the intervention group and $21.3 \%$ in the control group.

\section{Conclusion}

Given the positive effect of education based on the theory of planned behavior in changing the pregnant mothers' behavior, the theory can be used as a suitable intervention framework for implementing the educational programs to prevent urinary tract infections.

Trial registration

Name: Iranian Registry of Clinical Trials. Registration number: IRCT20170214032575N1. Registration date: 2019-12-12 [retrospectively registered].

\section{Background}

The urinary tract infection(UTI) is a common gynecological disease as a serious health problem in the world in the 21 st century, caused by the presence and proliferation of microorganisms in the urinary tract 
$(1,2)$. UTI affect 150 million people worldwide every year $(1,3,4)$, and one-third of all women experience urinary tract infections in their lifetime (5). This disease is more common in pregnant women than nonpregnant ones due to mechanical and hormonal changes during pregnancy (6-8). After anemia, UTI is the second most common health problem among pregnant women (9). Escherichia coli is the cause of $80-90 \%$ of urinary tract infections $(10-12)$. UTI in pregnancy occurs as symptomatic and asymptomatic bacteriuria among which the latter is the most common infection during pregnancy (13).

The prevalence of asymptomatic urinary tract infections compared to symptomatic infections is reported to be $2-15 \%$ in pregnant women $(14,15)$ and $6-11 \%$ in Iran $(16)$.

UTI has various complications on mothers and fetuses, including pyelonephritis, Pre-eclampsia (PE), anemia, septic shock, and Endometritis, premature delivery, and subsequently the fetal death, respiratory failure, low birth weight, mental retardation, intrauterine growth restriction, and IQ reduction (16-19).

Some health behaviors, such as not having frequent sexual activity, wearing appropriate underwear, and not delaying urination are behaviors that can prevent UTI. Despite the importance of these issues, many women do not have enough information about them, and studies indicate that women have low knowledge about the UTI prevention behavior $(16,20$, and 21$)$. In addition to knowledge, the individuals' attitudes, and way of thinking are also important factors in the possibility of UTI. For example, the individuals' perceptions that I may also have the urinary tract infection and the belief that urinary tract infections can be prevented by taking preventive behaviors can help prevent UTI $(13,22)$.

Subjective norms are other issues that can play important roles in UTI, reflecting the individuals' perception of whether or not others approve the behaviors. Therefore, if mothers feel that the urinary tract infection prevention behavior are approved and supported by family members, friends, health care staff, and other important people, they will show a greater desire to exhibit the behaviors that prevent UTI.

The present study emphasized the role of family, especially the husband, in maintaining sexual health (as informal abstract norms) to prevent UTI in pregnancy $(13,23,24)$.

Other studies have considered the effective and useful roles of subjective norms, physician, midwife (as formal norms), and family (as informal norms) in preventing disease.

The individuals' ability to perform certain behaviors, such as sexual behavior habits and personal hygiene, which play important roles in the development of UTI during pregnancy, is another factor that can affect UTI during pregnancy. This sense of ability is considered as the perceived behavioral control $(10,25)$.

Education can increase awareness, change attitudes, and create a sense of empowerment in individuals in the field of behaviors for preventing UTI. The theory of planned behavior is an important theory of behavioral change as the main framework of the present research. This theory is applicable to predict and understand behaviors. According to this theory, the behavioral intention is the most important 
determinant of behavior; and other main constructs of this theory (attitude, Subjective norms, and perceived behavioral control) affect this theory in special ways (26).

Given that influential factors such as the individuals' attitudes, presence of others, and the sense of control over the behaviors for preventing UTI are main issues in adopting behaviors for preventing the urinary tract infections, and they are constructs of theory of planned behavior, the present study was designed and conducted with an aim to determine the effect of education based on the theory of planned behavior on teaching behaviors for preventing UTI in pregnant women (Fig. 1).

\section{Methods}

\section{Study design}

The present study was a randomized controlled trial. The statistical population consisted of pregnant women who visited the comprehensive health service centers of Zarinshahr (a city in central Iran) in 2019 (Figure 2).

Inclusion criteria: being in the first trimester of pregnancy, not having a urinary tract infection based on a laboratory test, not having chronic diseases such as diabetes, not taking antibiotics and immunosuppressive drugs.

Exclusion criteria: Continuous absence from training sessions (absence of more than a session during the training intervention), non-completion of the questionnaire and referral due to medical urgency (abortion, etc.).

\section{Sampling method and calculation of sample size}

Sampling was randomly conducted in accordance with the population. In Zarinshahr, there are five comprehensive health service centers from which 100 pregnant women were randomly and systematically selected according to the list of pregnant women. A computer random-number generator was used to generate the random sequence for group allocation (50 individuals in the intervention group and 50 individuals in the control group). An investigator blinded to participants selection kept the random sequence and allocated the participants to intervention and control groups at a 1:1 ratio.

The sample size was obtained equal to 44 for each group according to the following equation, and 49 individuals in each group with a $10 \%$ drop.

$$
N=\frac{(Z 1+Z 2)^{2}(2 s)^{2}}{d^{2}}
$$

Z1: Confidence level of $95 \%$ was equal to 1.96.

Z2: The test power factor of $80 \%$ was equal to 0.84 . 
S: Estimation of the mean standard deviation of score for each variable in the two groups.

$\mathrm{d}$ : The minimum difference of mean scores of each variable between two groups, indicating a significant differences and was considered to be $0.6 \mathrm{~s}$.

$(1.96+0.84)^{2}(2 \mathrm{~S})^{2}$

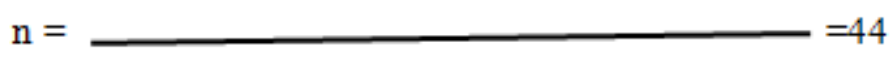

$0.36 \mathrm{~S}^{2}$

\section{Data collection method}

In the study, the data collection method included a questionnaire based on constructs of theory of planned behavior. The questionnaire consisted of three parts: the first part included demographic questions, the second part included questions about knowledge, and the third part included questions about constructs of the theory of planned behavior, and included questions about attitude, abstract norms, perceived behavioral control, and behavioral intention and behavior. There were 29 questions about knowledge, designed in Yes and No, and multi-choice questions. The correct option received score 1 , and wrong option was given score 0 . The knowledge scores ranged from 0 to 29 . For example, "Which one of cases were symptoms of the bladder infection?" About the attitude, 17 questions were designed in the questionnaire on a 5-point Likert scale from strongly agree to strongly disagree, and the scores ranged from 0 to 68. For example, "I may also have a urinary tract infection." The perceived behavioral control contained 18 questions which were scored similar to the attitude; and the scores ranged from 0 to 72 . For example, "I never hold urinating, even if the frequent urination is tiresome".

Three questions were designed based on the three-point Likert scale from high to low to evaluate the subjective norms in the questionnaire. The range of scores was from 0 and 6 . For example, "Spouses and other family members play significant roles in accepting the urinary tract infection prevention behavior". There were 7 questions for assessing the behavioral intention and they were designed based on a 5-point Likert scale with scores ranging from 0 to 28 . For example, "I am going to consume 8 glasses of water per day."

22 questions were considered to measure the behavior in a yes/no design; the correct answer was scored 1 , and the wrong answer was scored zero; and the scores ranged from 0 to 22 . For example, "I always wear cotton underwear". Finally, all scores were calculated based on 100 for ease of comparison.

\section{Validity and reliability of data collection tools}

The validity and reliability of the questionnaire were proven in a study by Shamsi et al. (22). The content validity ratio and content validity index were used to assess the validity of study; and the questionnaire validity was confirmed. The internal consistency method was used to determine the reliability so that 
Cronbach's alpha coefficients were 0.79 for knowledge, 0.86 for attitude, 0.70 for subjective norms, 0.71 for perceived behavioral control, 0.76 for behavioral intention, and 0.81 for behavior that confirmed the reliability.

\section{Intervention}

Telephone calls were made to invite women to attend the study. Five training sessions were held and designed and implemented based on the behavioral goals in order to improve the constructs of the theory of planned behavior. Table 1 presents a brief description of the training sessions (Table 1).

\section{Data analysis}

SPSS 20 software was used to analyze data. We used the independent t-test to analyze demographic variables (to analyze quantitative variables such as age), and Mann-Whitney test to analyze the rank qualitative variables such as education level, and Chi-square or Fisher's exact test to analyze the nominal qualitative variables such as gender. The repeated-measures analysis of variance compared the mean scores of the theory of planned behavior constructs and knowledge in each group before and after the intervention. The Kolmogorov-Smirnov test determined the data normality; and the Levene's test determined the equality of variances.

\section{Ethical considerations}

In the present study, the participants received complete information about the research purposes. They were also ensured that their information would remain confidential. The clinical trial was registered on the website of the Iranian Registry of Clinical Trials (IRCT20170214032575N1) and received a code of ethics (IR.MUI.RESEARCH.REC.1398.294) from the National Ethics Committee in the Iranian Biomedical Research (file:///C:/Users/DRshahnazi1/Downloads/4ed93mdxvizfn\%20(2).pdf).

\section{Results}

In the study, 46 individuals were examined in the intervention group with an age range of 17 to 42 years, and 47 individuals in the control group with an age range of 17 to 43 years.

Results of statistical tests indicated that two groups did not differ significantly in terms of demographic variables (Table 2).

Repeated-measures ANOVA indicated that scores of knowledge and constructs of the theory of planned behavior increased significantly in the intervention group over time $(P<0.001)$, while the difference was not significant in the control group over time (Table 3).

Chi-square test indicated that the frequency of urinary tract infections was significantly lower than the control group three months after the educational intervention in women of the intervention group (Figure $3)$. 


\section{Discussion}

The present study aimed to determine the effect of education based on the theory of planned behavior in adopting behaviors for preventing urinary tract infections in pregnant women. In the study, we examined the pregnant women's knowledge by measuring the existing problems before performing an educational intervention based on results of the pre-test, and then the pregnant mothers were received the necessary training in various fields such as recognizing symptoms of urinary tract infection, prevention methods, and testing to prevent urinary tract infections using the educational booklets and pamphlets, indicating an increase in the knowledge score of the intervention group after the program. The research finding was consistent with studies by Gonzalez et al (27), Haider et al (8), Indhumol et al (28). In the present study, the mean attitude score increased after the intervention, indicating the favorable effect of group discussion based on the theory of planned behavior. Therefore, the pregnant women divided into small groups and discussed issues about the ways to prevent the urinary infection. Under the supervision of the researcher, they exchanged views, and thus the individuals expressed their thoughts and ideas in this field and corrected them by the help of the researcher. The result was consistent with a study by Ahmed et al. (20). Since the family support is an important factor in adopting the urinary tract infection prevention behaviors, the husbands were asked to attend one of the training sessions with their wives to attract the family support. Since they were important subjective norms for their wives, their support were attracted properly. In the study, we saw an increase in mean scores of subjective norms in the post-training intervention group, while a meeting was held with the center's physician and midwife to provide counseling and support services and they were asked to provide the necessary support for pregnant women for education. Therefore, it seems that the guidance of health personnel through the theory of planned behavior in training classes will be very valuable and useful to prevent urinary tract infections in pregnant women. The result was consistent with results of studies by Abd El Aziz (7) and Nezhad Sadeghi. (13). The intervention result indicated an increase in mean score of perceived behavioral control in the intervention group. The increase could indicate the desired effect of education through role-playing, so that the behavior such as nutritional behaviors and way of dressing were simply and separately explained by the researcher in a way that each part of the behavior could be easily done by the pregnant woman. The pregnant mothers were then asked to play roles, leading to active thinking and participation and higher self-confidence in the participants. The result was consistent with a study by Song (29). In the study, the mean score of behavioral intention increased after the intervention. The increase in score might be due to the use of practical demonstration techniques in a way that foodstuffs such as barberry, Cornus mas, and water were displayed in the class and used symbolically by the participants to demonstrate proper eating habits. The result was consistent with a study by Conner et al. (30) and Shamsi et al. (22).

Findings of the present study indicated that the mean score of the urinary tract infection prevention behavior increased compared to the pre-intervention. The increase might be due to the use of film and practical screening, for example, a suitable pants for pregnancy was shown and a number of pregnant mothers wore loose and comfortable pants and showed other participants that not only there was no contraindication, but they were also suitable. The result was consistent with a study by Tehrani et al. (31), 
while it was different from a study by Ahmadi et al. (32) due to the differences between the research groups.

\section{Conclusion}

The research results indicated that the theory of planned behavior-based education, including the participants' attitudes and beliefs, had positive functional effects on most behaviors for preventing the urinary tract infections in pregnant women probably due to the fact that the education program sought to identify the participants' weaknesses through group discussion and provide the appropriate training, thereby changing the individuals' attitudes. The study also indicated that the perceived behavioral control as another construct of the theory could be strengthened in participating pregnant mothers and their selfconfidence could increase by relying on the role-playing. Using the practical display technique, the behavioral intention as another construct of the theory could be well developed in the learners' mind; and the desired behavior change could be made in learners using the film screening strategy. Therefore, the theory can be an appropriate intervention framework for implementing the educational programs to prevent urinary tract infections.

\section{Limitations}

Since the present study was conducted as a pilot in a city of Iran, the necessary precautions should be taken in generalizing the results to other regions.

\section{Abbreviations}

UTI: urinary tract infection; ANOVA: analysis of variance; TPB: theory of planned behavior

\section{Declarations}

\section{Ethics approval and consent to participate:}

Approval to conduct the study was obtained from the Research Ethics Committee of Isfahan University of Medical Sciences (ID- number: IR.MUI.REC.1396.3.578). Written informed consent was obtained from the participants. Furthermore, the pregnant women were informed that they had the right to withdraw from the study at any time, and were assured of the confidentiality of the study.

\section{Consent for publication:}

Not applicable.

\section{Availability of data and materials:}

The data that support the findings of this study are available from Deputy of research of Isfahan University of Medical Sciences but restrictions apply to the availability of these data, which were used 
under license for the current study, and so are not publicly available. Data are however available from the authors upon reasonable request and with permission of Isfahan University of Medical Sciences.

\section{Competing interests:}

The Authors declare that they have no competing interests.

\section{Funding:}

The Isfahan University of Medical Sciences funded this study as a part of a Master Thesis. However, this grant did not cover the most sections of this study.

\section{Authors' contributions:}

Initially conceived and designed the study: Hossein Shahnazi and Sheida Moradpour

Conducted the analysis: Akbar Hassanzadeh

Wrote the paper and made revisions: Sheida Moradpour and Hossein Shahnazi

Reviewing the manuscript critically: Hossein Shahnazi

The final version of the manuscript has been read and approved by all the authors, and the requirements for authorship have been met.

\section{Acknowledgements:}

The authors want to thank the all the participated pregnant women who are the main owners of this research.

\section{References}

1. Singh B, Tilak R, Srivastava R, Katiyar D. Urinary tract infection and its risk factors in women: an appraisal. J Pure Appl Microbiol. 2014;8(5):1-8.

2. Turay $A$, Eke $S$, Oleghe $P$, Ozekhome $M$. The prevalence of urinary tract infections among pregnant women attending antenatal clinic at Ujoelen primary health care centre, Ekpoma, Edo state, Nigeria. IJBA IR. 2014;3(3):86-94.

3. Flores-Mireles AL, Walker JN, Caparon M, Hultgren SJ. Urinary tract infections: epidemiology, mechanisms of infection and treatment options. Nat rev microbiol. 2015;13(5):269-84.[ doi:10.1038/nrmicro3432].

4. Abou Heidar NF, Degheili JA, Yacoubian AA, Khauli RB. Management of urinary tract infection in women: A practical approach for everyday practice. Urol Ann. 2019;11(4):339.[ doi:10.4103/UA.UA_104_19]. 
5. Oladeinde $\mathrm{BH}$, Omoregie R, Oladeinde $\mathrm{OB}$. Asymptomatic urinary tract infection among pregnant women receiving ante-natal care in a traditional birth home in Benin City, Nigeria. EthiopJ Health Sci. 2015;25(1):3-8.[ doi: 10.4314/ejhs.v25i1.2].

6. Jido TA. Urinary tract infections in pregnancy: evaluation of diagnostic framework. Saudi J Kidney Dis Transpl. 2014;25(1):85.[ doi: 10.4103/1319-2442.124496].

7. Abd El Aziz MS, Ibrahim HA-F, Elgzar WTI. Effect of application of health belief model on pregnant women'knowledge and health beliefs regarding urogenital infections. JNHS. 2016;5(5):34-44.[ DOI: 10.9790/1959-0505013444].

8. Haider G, Zehra N, Munir AA, Haider A. Risk factors of urinary tract infection in pregnancy. JPMA The JPakMed Assoc. 2010;60(3):213.

9. Szweda H, Jóźwik M. Urinary tract infections during pregnancy-an updated overview. Dev Period Med. 2016;20(4):263-72.

10. Amiri F, Rooshan M, Ahmady M, Soliamani M. Hygiene practices and sexual activity associated with urinary tract infection in pregnant women. EMHJ-Eastern Mediterr Health J.2009; 15 (1), 104-110.

11. Delzell Jr JE, Lefevre M. Urinary tract infections during pregnancy. Am fam physician. 2000;61(3):713-20.

12. Alemu A, Moges F, Shiferaw $Y$, Tafess $K$, Kassu A, Anagaw B, et al. Bacterial profile and drug susceptibility pattern of urinary tract infection in pregnant women at University of Gondar Teaching Hospital, Northwest Ethiopia. BMC res notes. 2012;5(1):197.[ doi: 10.1186/1756-0500-5-197].

13. Nezhad Sadeghi E, Solhi M. Effect of education based on health belief model on prevention of urinary infection in pregnant. HealthMED. 2012;6:4211-7.

14. Tadesse $\mathrm{E}$, Teshome M, Merid Y, Kibret B, Shimelis T. Asymptomatic urinary tract infection among pregnant women attending the antenatal clinic of Hawassa Referral Hospital, Southern Ethiopia. BMC res notes. 2014;7(1):155.[ doi: 10.1186/1756-0500-7-155].

15. Schnarr J, Smaill F. Asymptomatic bacteriuria and symptomatic urinary tract infections in pregnancy. Eur J Clin Invest. 2008;38:50-7.[ doi: 10.1111/j.1365-2362.2008.02009.x].

16. Noroozi F, Noroozi A, Tahmasebi R. Influencing factors in the health promoting behaviors of Urinary system based on health belief model in pregnant women in Bushehr 2013-14. ISMJ. 2015;18(3):597606. [in persian].

17. Derese B, Kedir H, Teklemariam Z, Weldegebreal F, Balakrishnan S. Bacterial profile of urinary tract infection and antimicrobial susceptibility pattern among pregnant women attending at Antenatal Clinic in Dil Chora Referral Hospital, Dire Dawa, Eastern Ethiopia. Ther clin risk manag. 2016;12:251.[ doi: 10.2147/TCRM.S99831. eCollection 2016].

18. Emiru T, Beyene G, Tsegaye W, Melaku S. Associated risk factors of urinary tract infection among pregnant women at Felege Hiwot Referral Hospital, Bahir Dar, North West Ethiopia. BMC res notes. 2013;6(1):292.[ doi: 10.1186/1756-0500-6-292].

19. Alidadi A. Evaluation of Knowledge, Attitude and Behavior in the Field of Urinary Tract Infection among the Iranian Pregnant Women, Based on the Health Belief Model (HBM): A systematic review. 
Int J Adv Multidiscip Res. 2018;5(12):68-74.[ DOI: http://dx.doi.org/10.22192/ijamr.2018.05.12.007].

20. Ahmed NM, Khresheh RMH. Impact Of Instructional Program About Prevention Of UTI Recurrence On The Level Of Knowledge And Self-Care Behaviors Among Women With UTI In Saudi Arabia.JNHS. 2016;5(3):43-51.[ DOI: 10.9790/1959-0503034351].

21. Hassan MHA. Effect of intervention guidelines on self care practices of pregnant women with urinary tract infection. Life Sci J. 2015;12(1):113-24.[ doi:10.7537/marslsj120115.16].

22. Shamsi M, Roozbehani N, Kabir K. Preventive behaviors of urinary tract infection (UTI) based on the theory of planned behavior among pregnant women in Karaj in 2013. Daneshvar. 2013;21(5):59-66. [in persian].

23. dos Santos Fioravante FF, de Carvalho Queluci G.. Online Braz J Nurs. 2017;16(1):28-36.

24. Badran YA, El-Kashef TA, Abdelaziz AS, Ali MM. Impact of genital hygiene and sexual activity on urinary tract infection during pregnancy. Urol ann. 2015;7(4):478.[ doi:10.4103/0974-7796.157971].

25. Nikpour S, Tabrizian L, D Roodsari M, Haghani H. Study of predisposing factors of urinary tract infections among married women referred to selected hospitals in Tehran city (2003). Razi Journal of Medical Sciences. 2004;11(41):489-97.[in persian].

26. Glanz K, Rimer BK, Viswanath K. Health Behavior And Health Education:Theory,Research,And Practice. 4th ed. United States: John Wiley And Sons; 2008. 592.

27. Gonzalez G, Vaculik K, Khalil C, Zektser Y, Arnold C, Almario CV, et al. Women's Experience with Stress Urinary Incontinence: Insights from Social Media Analytics. The J Urol. 2020;203(5):962-8.[ DOI: 10.1097/JU.0000000000000706]

28. Indhumol T, Pavithran S, George LK. Effectiveness Of Structured Teaching Program On Knowledge Regarding Prevention Of Urinary Tract Infection Among Adolescent Girls. Int J Pharm Med and BioSc. 2014;3(3):121.

29. Song KJ. The effects of self-efficacy promoting cardiac rehabilitation program on self-efficacy, health behavior, and quality of life. JKAN. 2003;33(4):510-8.[ doi: 10.4040/jkan.2003.33.4.510].

30. Conner M, Higgins AR. Long-term effects of implementation intentions on prevention of smoking uptake among adolescents: a cluster randomized controlled trial. Health Psychol. 2010;29(5):529.[ doi:10.1037/a0020317].

31. Tehrani FJ, Nikpour S, Kazemi EAH, Sanaie N, Panahi SAS. The effect of education based on health belief model on health beliefs of women with urinary tract infection. Int $\mathrm{J}$ community based nurs midwifery. 2014;2(1):2.

32. Ahmadi Z, Shamsi M, Roozbahani N, Moradzadeh R. The effect of educational intervention program on promoting preventive behaviors of urinary tract infection in girls: a randomized controlled trial. BMC pediatr. 2020;20(1):1-10.[ doi: 10.1186/s12887-020-1981-x].

\section{Tables}


Table 1-Summary of goals and strategies used in training sessions based on the constructs of the theory of planned behavior 


\begin{tabular}{|c|c|c|c|}
\hline Constructs & Behavioral goals of education & Domain & $\begin{array}{l}\text { Education } \\
\text { method }\end{array}$ \\
\hline \multirow[t]{3}{*}{ Knowledge } & $\begin{array}{l}\text { Pregnant women should define the urinary tract } \\
\text { infection in at least a sentence. }\end{array}$ & Cognitive & $\begin{array}{l}\text { Lecture, } \\
\text { question and } \\
\text { answer }\end{array}$ \\
\hline & $\begin{array}{l}\text { Pregnant women should describe at least five } \\
\text { symptoms of a bladder infection. }\end{array}$ & Cognitive & $\begin{array}{l}\text { Lecture, } \\
\text { question and } \\
\text { answer }\end{array}$ \\
\hline & $\begin{array}{l}\text { Pregnant women should name various ways to prevent } \\
\text { urinary tract infections. }\end{array}$ & Cognitive & $\begin{array}{l}\text { Lecture, } \\
\text { question and } \\
\text { answer }\end{array}$ \\
\hline \multirow[t]{3}{*}{ Attitude } & $\begin{array}{l}\text { Pregnant women should understand the importance of } \\
\text { having the urinary tract infections during their } \\
\text { pregnancy and discuss it for } 5 \text { minutes. }\end{array}$ & Affective & $\begin{array}{l}\text { Lecture, } \\
\text { group } \\
\text { discussion, } \\
\text { and } \\
\text { brainstorming }\end{array}$ \\
\hline & $\begin{array}{l}\text { Pregnant women discuss the side effects of urinary } \\
\text { tract infections on infants and mothers and discuss } \\
\text { them for } 5 \text { minutes. }\end{array}$ & $\begin{array}{l}\text { Cognitive, } \\
\text { Affective }\end{array}$ & $\begin{array}{l}\text { Lecture, } \\
\text { group } \\
\text { discussion, } \\
\text { and } \\
\text { brainstorming }\end{array}$ \\
\hline & $\begin{array}{l}\text { Pregnant women should discuss ways to prevent } \\
\text { urinary tract infections and discuss them for } 5 \text { minutes. }\end{array}$ & $\begin{array}{l}\text { Cognitive, } \\
\text { Affective }\end{array}$ & $\begin{array}{l}\text { Lecture, } \\
\text { group } \\
\text { discussion, } \\
\text { and } \\
\text { brainstorming }\end{array}$ \\
\hline \multirow[t]{3}{*}{$\begin{array}{l}\text { Subjective } \\
\text { norms }\end{array}$} & $\begin{array}{l}\text { Pregnant women should be encouraged to perform } \\
\text { urinary tract infection prevention behaviors by others. }\end{array}$ & Affective & $\begin{array}{l}\text { Lecture, } \\
\text { question and } \\
\text { answer }\end{array}$ \\
\hline & $\begin{array}{l}\text { Pregnant women should be introduced to the roles of } \\
\text { influential individuals (doctors, midwives, family } \\
\text { members, and friends) in preventing the urinary tract } \\
\text { infections and discuss them for } 5 \text { minutes. }\end{array}$ & $\begin{array}{l}\text { Cognitive, } \\
\text { Affective }\end{array}$ & $\begin{array}{l}\text { Group } \\
\text { discussion, } \\
\text { and } \\
\text { brainstorming }\end{array}$ \\
\hline & $\begin{array}{l}\text { Pregnant women should understand the attitudes of } \\
\text { those around them towards their urinary tract infection } \\
\text { prevention behaviors and discuss them for } 5 \text { minutes. }\end{array}$ & Affective & $\begin{array}{l}\text { Group } \\
\text { discussion }\end{array}$ \\
\hline \multirow{2}{*}{$\begin{array}{l}\text { Perceived } \\
\text { behavioral } \\
\text { control }\end{array}$} & $\begin{array}{l}\text { Pregnant women should feel empowered to do the right } \\
\text { nutritional behaviors and how to dress. }\end{array}$ & $\begin{array}{l}\text { Psycho- } \\
\text { motor }\end{array}$ & Role playing \\
\hline & $\begin{array}{l}\text { Pregnant women should maintain their sexual and } \\
\text { urinary hygiene. }\end{array}$ & $\begin{array}{l}\text { Psycho- } \\
\text { motor }\end{array}$ & $\begin{array}{l}\text { Group } \\
\text { discussion }\end{array}$ \\
\hline \multirow[t]{2}{*}{$\begin{array}{l}\text { Behavioral } \\
\text { intention }\end{array}$} & $\begin{array}{l}\text { Pregnant women should change their underwear at } \\
\text { least } 3 \text { times a week for the next } 2 \text { weeks. }\end{array}$ & $\begin{array}{l}\text { Cognitive, } \\
\text { Emotional }\end{array}$ & $\begin{array}{l}\text { Lecture, } \\
\text { group } \\
\text { discussion, } \\
\text { and } \\
\text { brainstorming }\end{array}$ \\
\hline & Pregnant women should decide to wear baggy pants & Psycho- & Practical \\
\hline
\end{tabular}


Table 2 - Comparison of demographic variables in the research groups

\begin{tabular}{|c|c|c|c|}
\hline Variable & Intervention group & Control group & P-value \\
\hline \multicolumn{4}{|l|}{ Job } \\
\hline Housewife & $42(91.3)$ & $46(97.9)$ & $0.17 *$ \\
\hline Employee & $4(8.7)$ & $1(2.1)$ & \\
\hline \multicolumn{4}{|l|}{ Place of residence } \\
\hline Personal & $25(54.3)$ & $20(42.6)$ & 0.25 ** \\
\hline Rental & $21(45.7)$ & $27(57.4)$ & \\
\hline \multicolumn{4}{|l|}{ Education level } \\
\hline Under high school diploma & $6(13)$ & $5(10.6)$ & \\
\hline high school diploma and associate degree & $23(50)$ & $9(19.2)$ & $0.13^{\star \star \star}$ \\
\hline Bachelor & $17(37)$ & $33(70.2)$ & \\
\hline \multicolumn{4}{|l|}{ Monthly income } \\
\hline Less than 10 million Rials & $3(6.5)$ & $5(10.6)$ & \\
\hline 10-20 million Rials & $13(28.3)$ & $9(19.2)$ & 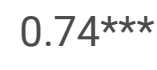 \\
\hline More than 20 million Rials & $30(65.2)$ & $33(70.2)$ & \\
\hline
\end{tabular}

* Fisher's exact test

** Chi-square test

$\star \star \star$ Mann-Whitney test

Table 3- Comparison of mean scores (from 100) of knowledge and constructs of theory of planned behavior before and after the intervention in control and intervention groups 


\begin{tabular}{|c|c|c|c|c|c|}
\hline \multirow[t]{2}{*}{ Construct } & \multirow[t]{2}{*}{ Group } & $\begin{array}{l}\text { Before the } \\
\text { intervention }\end{array}$ & $\begin{array}{l}\text { Immediately after } \\
\text { the intervention }\end{array}$ & $\begin{array}{l}\text { Three months after } \\
\text { the intervention }\end{array}$ & \multirow[t]{2}{*}{$\begin{array}{l}\text { P- } \\
\text { value* }\end{array}$} \\
\hline & & Mean (sd) & Mean (sd) & Mean (sd) & \\
\hline \multirow[t]{2}{*}{ Knowledge } & Intervention & $51.4(17.2)$ & $94.9(4.2)$ & $88.2(9.2)$ & \multirow[t]{2}{*}{$<0.001$} \\
\hline & Control & $49.3(13.5)$ & $55.7(12.2)$ & $59.6(13.8)$ & \\
\hline \multirow[t]{2}{*}{ Attitude } & Intervention & 70.9 (12.7) & $90.4(7.9)$ & $87.9(9.3)$ & \multirow[t]{2}{*}{$<0.001$} \\
\hline & Control & $71.2(11.1)$ & $72.4(10.6)$ & 73.9 (11.1) & \\
\hline \multirow{2}{*}{$\begin{array}{l}\text { Subjective } \\
\text { norms }\end{array}$} & Intervention & $85(25.3)$ & $98.5(7.1)$ & $96.2(12.9)$ & \multirow[t]{2}{*}{0.04} \\
\hline & Control & $85.3(25.2)$ & $85.4(24.1)$ & $85.4(30.3)$ & \\
\hline \multirow{2}{*}{$\begin{array}{l}\text { Perceived } \\
\text { behavioral } \\
\text { control }\end{array}$} & Intervention & $75.5(14.2)$ & $92.1(9.6)$ & $90.1(9.3)$ & \multirow[t]{2}{*}{$<0.001$} \\
\hline & Control & $76.6(10.5)$ & $70.1(10.8)$ & 76.5 (14) & \\
\hline \multirow{2}{*}{$\begin{array}{l}\text { Behavioral } \\
\text { intention }\end{array}$} & Intervention & $81.2(15.3)$ & $93.1(10.4)$ & $93.1(8.8)$ & \multirow[t]{2}{*}{$<0.001$} \\
\hline & Control & $79.3(13.6)$ & $73.9(12.1)$ & $80.9(16.7)$ & \\
\hline \multirow[t]{2}{*}{ Behavior } & Intervention & $71.5(14.5)$ & $97.1(4.8)$ & $95.9(6.2)$ & \multirow[t]{2}{*}{$<0.001$} \\
\hline & Control & $75.2(14)$ & $73.8(17.3)$ & $79(16.1)$ & \\
\hline
\end{tabular}

*Repeated M ANOVA

Figures 


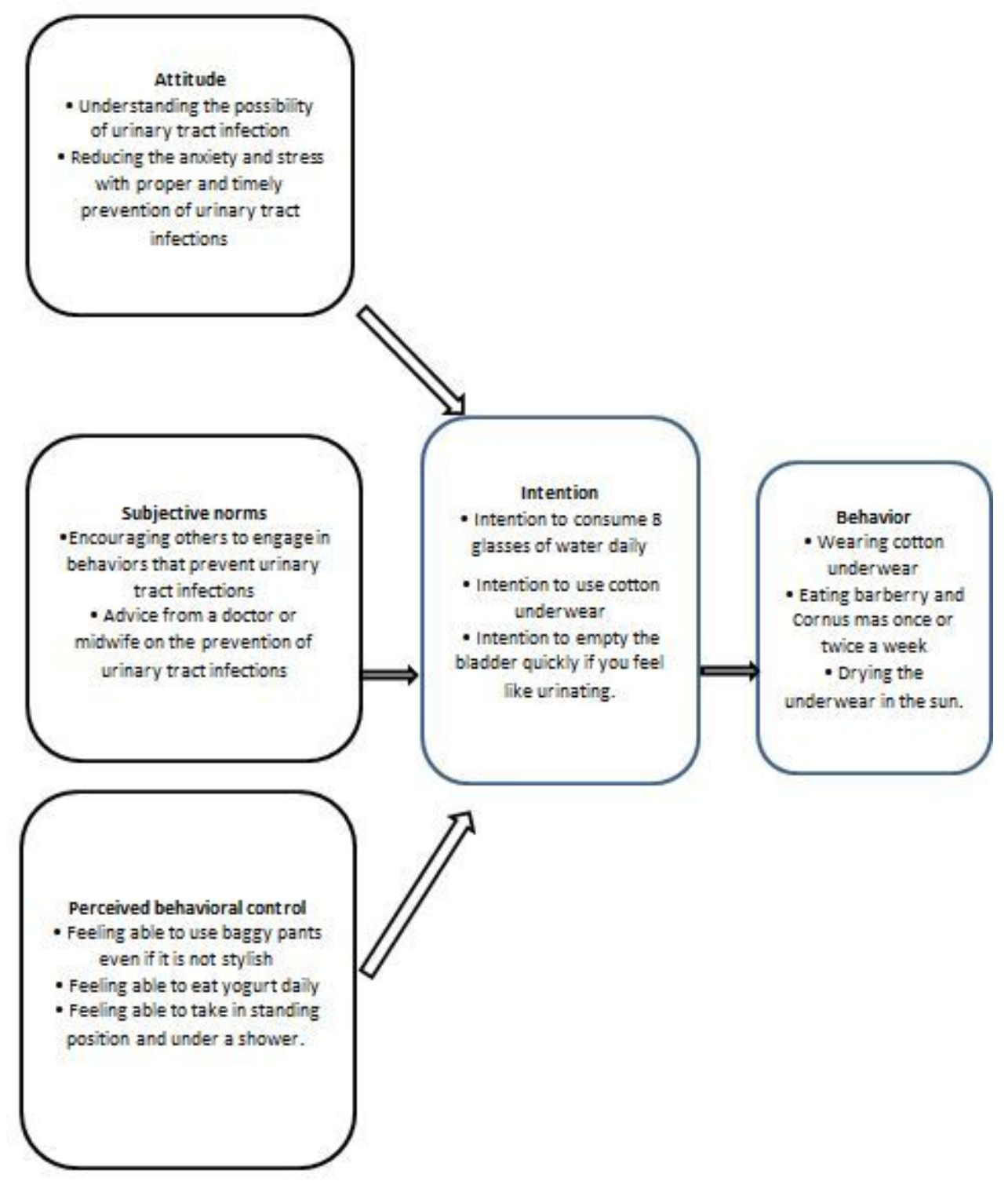

Figure 1

Conceptual framework of the study based on the theory of planned behavior 


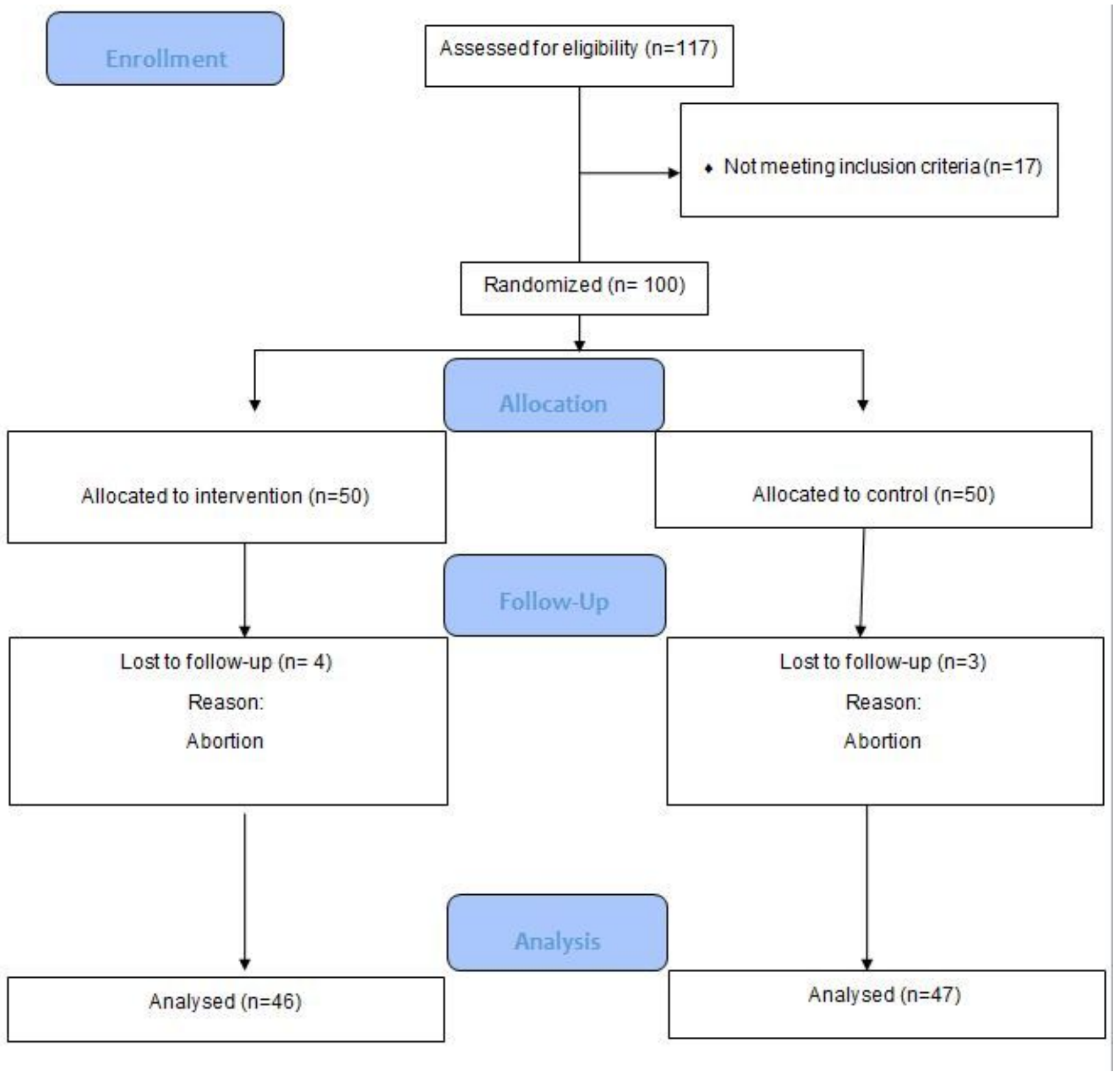

Figure 2

CONSORT Flow Diagram 
25

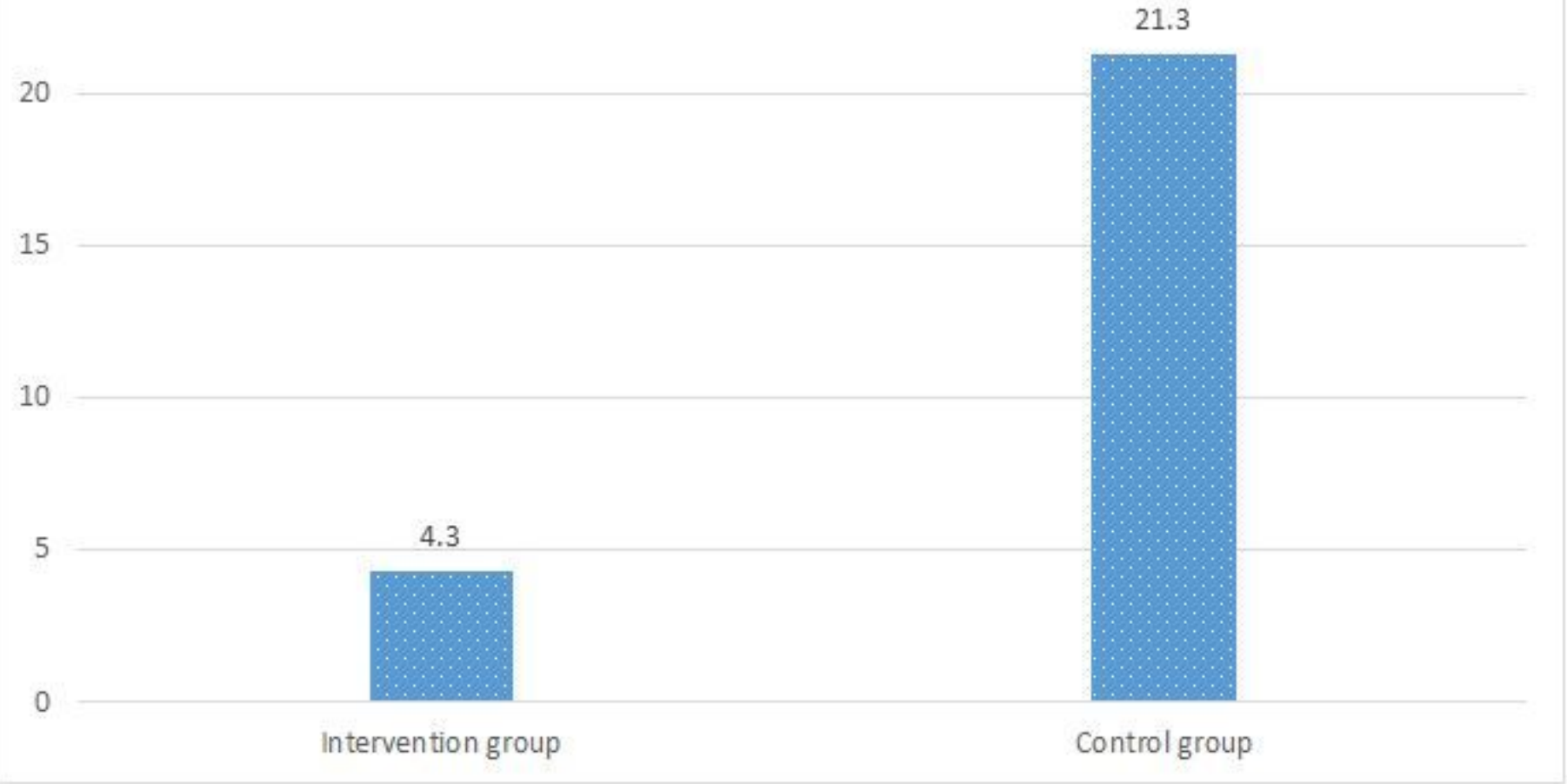

Figure 3

Frequency percentage of urinary tract infection in both groups after intervention 